\title{
In memoriam prof.dr. M. Timmer
}

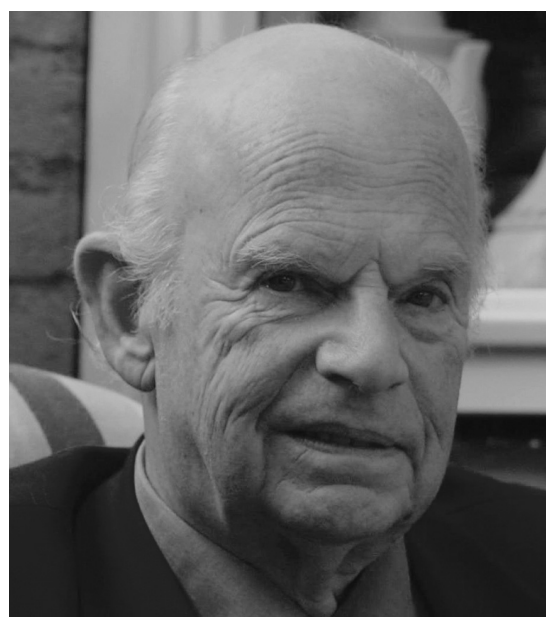

Met zijn dood op 6 april 2009 kwam een einde aan het veelbewogen leven van prof.dr. Maarten Timmer, emeritus hoogleraar sociale verzekeringsgeneeskunde van de UvA. Hij stierf na een slopende ziekte zoals hij was: manmoedig en realistisch. Zijn geest bleef gelukkig tot op het laatst lucide, zelfs vlak voor zijn dood was hij begaan met het lot van zijn oud-stafleden.

Timmer groeide op in een gereformeerd onderwijzersgezin, waar ijver, discipline, spaarzaamheid, en daadkracht haast vanzelfsprekend waren. Wie het heldenkerkhof iat wa shem in Jeruzalem bezoekt, vindt daar een bordje met de naam van zijn ouders. Maarten stamde ook af van Texelse vissers, wellicht had hij daarom een avontuurlijke geest voor en zin in het nieuwe en het ongebruikelijke. In I 953 vertrok hij, na een korte chirurgische opleiding, naar Indonesië in de postkoloniale periode. Diplomatie was nodig om te overleven. Het leven was bovendien karig en zwaar. In het Bethesda ziekenhuis te Djokjakarta kreeg hij de leiding over de kinderafdeling, en werd hij door de bekende pediater Paredo tot kinderarts opgeleid. Ondertussen werkte hij ook aan een dissertatie, een omvangrijke sociaal-geneeskundige studie over 'Child mortality and population pressure'. Dit proefschrift zou diverse drukken beleven en grote invloed krijgen op het bevolkingsbeleid in Indonesië. De tropen lieten Timmer ook later nooit los. Hij bleef nog vele jaren leiding geven aan tropenmissies bij uiteenlopende ontwikkelingsprojecten. Veelal betrof dit mother and child health care met name in Nepal en Indonesië.

$\mathrm{Na}$ ommekomst in Nederland was er de zorg voor een groot gezin. Hij ondervond dezelfde problemen als zoveel remigrerende tropenartsen. Hij was enkele jaren huisarts. Naast zijn drukke werkzaamheden schreef hij talloze artikelen over sociaal-geneeskundige vraagstukken waarin hij zijn pediatrische kennis kon laten doorklinken. Timmer had een natuurlijke gezag, waardoor hij veelvuldig voor bestuursfuncties werd uitgenodigd, onder andere in de Nederlandse Gezinsraad.
Na enkele huisartsenjaren opteerde hij voor een wetenschappelijke carrière bij de afdeling Sociale Geneeskunde aan de Vrije Universiteit.

In I976 werd hij hoofd van het Bureau Wetenschappelijk onderzoek van de GMD. Binnen dit bureau werd een nieuw referentiekader ontwikkeld dat een nieuwe wetenschappelijke basis zou geven aan de verzekeringsgeneeskundige oordeelsvorming. Hij zou daarom de grondlegger van de moderne verzekeringsgeneeskunde worden. Zijn betekenis voor de verzekeringsgeneeskunde is groot geweest. Om dit vakgebied meer te profileren gaf hij een nieuw tijdschrift vorm, het Tijdschrift voor Verzekeringsgeneeskunde dat later zou opgaan in het Tijdschrift voor Bedrijfs-en Verzekeringsgeneeskunde. Op 27 oktober I986 aanvaardde hij het extraordinariaat Verzekeringsgeneeskunde aan de UvA met de inaugurele rede getiteld: Sociale verzekeringsgeneeskunde als wetenschap. In die oratie werd al gewezen op de noodzaak om de professionalisering van de verzekeringsartsen meer te baseren op wetenschappelijke kennis. Aan de versterking van de identiteit van de sociale verzekeringsgeneeskunde heeft Maarten Timmer vervolgens zijn hele carrière met succes gewerkt.

De pensioenleeftijd (I990) gaf ruimte voor zijn opus magnum: de encyclopedie van Anima tot Zeus, waaraan hij Io jaar heeft gewerkt. Het is een standaardwerk geworden van begrippen uit de (niet-westerse) cultuurgeschiedenis en de analytische psychologie.

Timmer had een grote daadkracht en hij wist op het juiste moment steeds de juiste beslissingen te nemen. Binnen zijn afdeling was het goed werken, creativiteit werd hier sterk bevorderd. Tekenend voor de stimulerende ambiance binnen zijn afdeling was dat hij bij zijn afscheid als hoogleraar een liber amicorum kreeg aangeboden. Zijn verdiensten werden ook landelijk erkend met zijn benoeming tot Ridder in de Orde van OranjeNassau en tal van andere onderscheidingen.

Wij zullen Maarten herdenken als de grondlegger van de moderne visie op de verzekeringsgeneeskundige weging van belasting en belastbaarheid.

Jan Willem Koten, Han Willems en Nico Croon 